\title{
Hide and seek: is the solitary bee Monoeca haemorrhoidalis trying to escape from its cleptoparasite Protosiris gigas (Hymenoptera, Apidae: Tapinotaspidini; Osirini)?
}

\author{
Léo Correia da Rocha-FiLho ${ }^{1}$, Gabriel A. R. Melo ${ }^{2}$ \\ ${ }^{1}$ Departamento de Biologia, Faculdade de Filosofia, Ciências e Letras de Ribeirão Preto-FFCLRP, Universidade de São \\ Paulo-USP, 14040-901, Ribeirão Preto, São Paulo, Brazil \\ ${ }^{2}$ Laboratório de Biologia Comparada de Hymenoptera, Departamento de Zoologia, Universidade Federal do Paraná, \\ Curitiba, PR 80060-000, Brazil
}

Received 27 January 2016 - Revised 12 August 2016 - Accepted 23 August 2016

\begin{abstract}
Cleptoparasites play a key ecological role by reducing their host populations. In order to study the phenological patterns of the natural enemies of the bee Monoeca haemorrhoidalis (Smith), four emergence traps were installed in two nest aggregations during the activity period of this solitary bee species. Four species of natural enemies were sampled in the emergence traps: Tetraolytta gerardi (Pic), Tetraonyx distincticollis Pic (Meloidae), Protosiris gigas Melo (Apidae), and Pseudomethoca spixi (Diller) (Mutillidae). Monoeca haemorrhoidalis showed emergence patterns characterized by bimodal curves with two distinct peaks throughout its activity period in both years. Individuals of $P$. gigas started to emerge during the first peak of its host, but the emergence curve of this cleptoparasite was followed by a decline in abundance of $M$. haemorrhoidalis specimens in both years. The abrupt decline in the emergence period of $M$. haemorrhoidalis could be a temporal strategy against the attack of $P$. gigas since the activity period of this cuckoo bee occurred during the lowest number of emergent host individuals.
\end{abstract}

\section{cleptoparasitism / host-parasite relationship / natural enemy / temporal segregation}

\section{INTRODUCTION}

Cleptoparasitism is a phenomenon widely observed among solitary bee and wasp species (Evans 1966; Batra 1984; O’Neill 2001; Michener 2007). By definition, a cleptoparasitic female invades a host nest and deposits her egg in one or more brood cells and its larvae feed on the provisions stored by the host female for her offspring. The host larvae can be killed by the cleptoparasitic female or by the parasite larvae, which have specialized sharp mandibles (Wcislo 1987). Cleptoparasites thus avoid the costs of brood care (Wcislo 1987) which include both nest construction and food collection.

Corresponding author: L. Rocha-Filho, correiadarocha@yahoo.com.br Manuscript editor: James Nieh
Cleptoparasites exert an environmental pressure on the reproductive biology of their hosts. In some cases, the attack performed by those brood parasites is the dominant mortality factor of immature bees and wasps' species (Bohart et al. 1960; Rozen 1984; Rosenheim 1987; Vinson et al. 1987), even provoking local extinction of nest aggregations (Batra 1966; Simon-Thomas and Simon-Thomas 1972; Knerer 1973).

Cleptoparasites employ different mechanisms and strategies to reach brood cells without being detected by their hosts. A common behavior that has been widely documented is displayed by some females that land near the host nest entrance and wait for the host female to leave her nest (Bohart and Youssef 1972; Rozen and Snelling 1986; Garófalo and Rozen 2001; Alves-dos-Santos et al. 2002; Vinson et al. 2011). Other brood parasitic species possess a similar qualitative pattern of odor compounds from the mandibular glands or 
cuticular hydrocarbons to their host species. This chemical camouflage would permit the parasitic females to invade the nests undetected by olfaction (Tengö and Bergström 1977; Strohm et al. 2008). A remarkable strategy recently documented by Winterhagen (2015) shows that the chrysidid Omalus biaccinctus (Buysson) oviposits on living aphids that will be collected by the host wasp as prey, thus avoiding the risk of confrontations with host females by an indirect access to the nests.

Host species, in turn, have evolved counterstrategies to reduce the mortality rates caused by brood parasites. Within the tactics of parasite avoidance employed by host bees and wasps are spatial and temporal strategies (Rosenheim 1989; Strohm et al. 2001), aggregated nesting (Rosenheim 1990), and aggressive behavior against female parasites (Bohart and Youssef 1972; Rocha-Filho et al. 2008).

In a study on the nesting biology of the solitary bee Monoeca haemorrhoidalis (Smith), RochaFilho \& Melo (2011) recorded 27 species of natural enemies associated with the nest aggregations. Only four of them-the meloid beetles Tetraolytta gerardi (Pic) and Tetraonyx distincticollis Pic, the cuckoo bee Protosiris gigas Melo (Apidae), and the parasitoid wasp Pseudomethoca spixi (Diller) (cited as P. melanocephala) (Mutillidae)—were sampled in emergence traps set in two nest aggregations of the host bee. Herein, we aim to investigate the following questions: Are the seasonality patterns of the different natural enemies of $M$. haemorrhoidalis synchronized? In particular, is there synchrony between host and cleptoparasite bee activity periods?

\section{MATERIAL AND METHODS}

\subsection{Study site}

Fieldwork was carried out at the Área de Proteção Ambiental Mananciais da Serra (MS) $\left(25^{\circ} 29^{\prime}\right.$ S, 48 $58^{\prime}$ W), between 900 and $1400 \mathrm{~m}$ above sea level, in eastern Paraná State, southern Brazil. This area is covered with intact Atlantic forest and encompasses 2340 ha (ITCF 1987; Struminski 2001). The climate of this region is characterized by high rainfall in all months, rainy summers, and winters marked by occurrence of frosts. The mean annual temperature oscillates between 15 to $19{ }^{\circ} \mathrm{C}$, the relative humidity varies from 80 to $85 \%$, and annual precipitation can reach $2500 \mathrm{~mm}$ (Maak 2002). Climatological data were obtained from the Instituto Meteorológico SIMEPAR (Sistema Meteorológico do Paraná), of the Meteorological Station of Pinhais, the closest station to the study area.

\subsection{Nest aggregations}

Two of the four nest sites (B and D) studied by Rocha-Filho and Melo (2011) were selected for installation of the emergence traps. Both nest areas are located in exposed areas along the main trail that crosses the reserve. Nest site B $\left(25^{\circ} 29^{\prime} 60^{\prime \prime} \mathrm{S}\right.$ and $\left.48^{\circ} 59^{\prime} 03^{\prime \prime} \mathrm{W}\right)$ is located in an open area inside the forest, and it covers an area of $100 \mathrm{~m}^{2}$, while nest site D $\left(25^{\circ} 28^{\prime} 44^{\prime \prime} \mathrm{S}\right.$ and $48^{\circ} 58^{\prime} 08^{\prime \prime} \mathrm{W}$ ) is $138 \mathrm{~m}^{2}$ and at the end of the reserve main trail. The two study sites are approximately $2500 \mathrm{~m}$ apart from each other. Rozen et al. (2006) and Rocha-Filho and Melo (2011) recorded the presence of the cuckoo bee $P$. gigas only at nest site D. For additional details on the nest site characteristics, see RochaFilho and Melo (2011).

\subsection{Emergence traps}

In order to obtain information regarding sex ratio, emergence period, survey of natural enemies, and their parasitism rate, emergence traps (Figure 1a) were set up at the nest sites. These traps consisted of a $50 \mathrm{~cm}$ high pyramidal frame made of wood poles, with a basal area of $1 \mathrm{~m}^{2}$ and an apical area of $0.03 \mathrm{~m}^{2}$. The frame was covered with black tulle and capped with an inverted plastic container with a central opening surrounded by a well which contained a preservative consisting of $10 \mathrm{~mL}$ of $10 \%$ formaldehyde in 11 of water, which was replaced monthly. This container was surrounded by another to prevent insects escape.

Two emergence traps were randomly arranged at each nest site giving a total of $4 \mathrm{~m}^{2}$ of sampled area. The emergence traps were installed in September 2005 and September 2006 before the nest activities of M. haemorrhoidalis had started. The position of the traps in the nest aggregations was changed from 1 year to the other. Data collection was performed weekly until 1 week after the end of the activity period of M. haemorrhoidalis in both years. This species has a univoltine life cycle; adults are active between October and March (Rocha-Filho and Melo 2011). Rocha-Filho and Melo (2011) observed that there was an expectation 

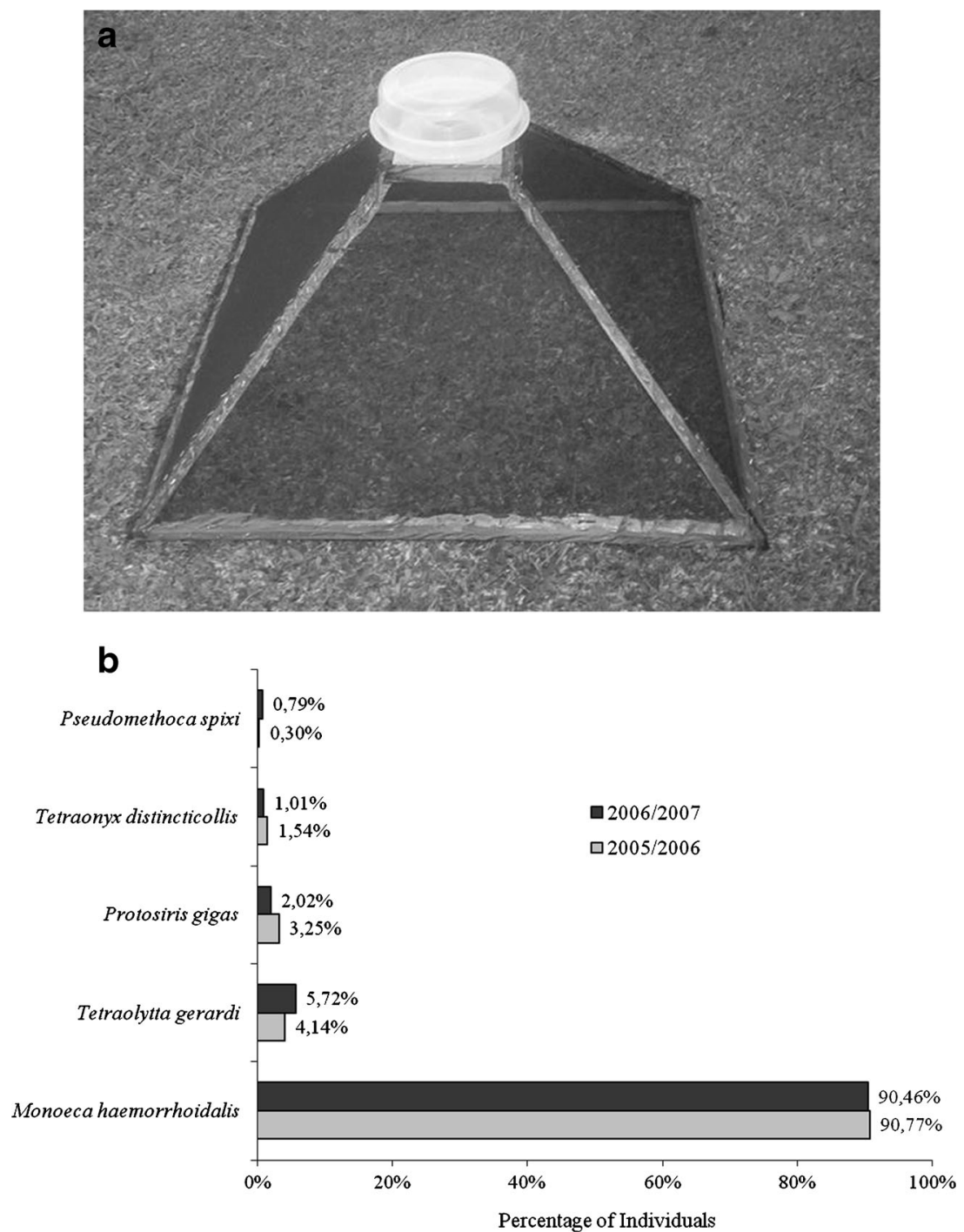

Figure 1. a Emergence trap model set in the nest aggregations of Monoeca haemorrhoidalis . Photo: Kelli Ramos. b Percentage of Monoeca haemorrhoidalis specimens and of its natural enemies that emerged in the traps set in areas $\mathrm{B}$ and $\mathrm{D}$ in the nesting sites, in southern Brazil

of approximately 1 month in the activity period of M. haemorrhoidalis from 1 year to the next. Considering this result, fieldwork was conducted from 24 September 2005 to 04 March 2006 in the first year (year 1), for a total of 162 days, while in the second year the emergence traps were inspected over a total of 142 days between 25 September 2006 to 12 February 2007 (year 2).

All insects that emerged in the traps were deposited as voucher specimens in the Entomological Collection
Padre Jesus Santiago Moure of the Zoology Department of Universidade Federal do Paraná (DZUP).

\section{RESULTS}

During the whole period in which the emergence traps were set in the field, five species represented by 2581 individuals were sampled as follows by order of abundance: $M$. haemorrhoidalis (2340), $T$. gerardi (124), P. gigas (73), T. distincticollis (35), 
and P. spixi (9) (Figure 1b). Additional insects belonging to Orthoptera, Coleoptera, Diptera, Lepidoptera, and Hymenoptera also emerged in the traps kept in the nest aggregations. However, these taxa were considered unlikely to be directly associated with the bees or the Meloidae encountered (Bologna and Pinto 2007; Rocha-Filho and Melo 2011).

Considering only the host species and its parasites, a total of 1690 specimens were collected in the emergence traps in the first year. The most representative species was $M$. haemorrhoidalis with 1534 individuals, ca of $91 \%$ of the total sampled (Figure 1b). The sex ratio for this species was strongly female biased in 1.65:1 $\left(\chi^{2}=46.28\right.$; $P<0.0001$; 954 females and 580 males). The emergence pattern of $M$. haemorrhoidalis presented a bimodal distribution with a higher peak between November 11th and November 27th of 2005 and a lower peak between December 30th of 2005 and January 20th of 2006 (Figure 2a). Both females and males started emerging by October 22nd, 2005; the emergence period of males ceased at February 3rd of 2006, and the last females emerged at February 25th of 2006.

The numbers of individuals collected in the emergence traps during the second year corresponded to only $53 \%$ (891 specimens) of that recorded in the first year. As before, $M$. haemorrhoidalis was the most common species with 806 individuals (90.5\%) (Figure 2b). Four hundred sixty-one females $(57.2 \%)$ and 345 males $(42.8 \%)$ emerged. The sex ratio was also strongly female biased $(1.37: 1)$ as found in the first year $\left(\chi^{2}=8.39 ; \mathrm{df}=1 ; P=0.003\right)$. The emergence pattern was also bimodal with one peak between October 23rd and 30th and another between December 25th of 2006 and January 8th of 2007 (Figure 2b).

In both years, $M$. haemorrhoidalis exhibited an emergence pattern characterized by a bimodal curve with two distinct peaks throughout its activity period (Figure 2). In the first year, the sharp decline in emergence between the two emergence peaks occurred in December (Figure 2a), the month with the least precipitation. The low rainfall may cause the soil to dry out too much for M. haemorrhoidalis females that nest in wet clay soil (Rocha-Filho and Melo 2011). Nevertheless, in the second year, the emergence decline did not occur in a period marked by low precipitation once the lowest accumulated precipitation values were recorded in October and December (Figure 3), while the lowest abundance of M. haemorrhoidalis was observed in November and the beginning of December (Figure 2b).

The sharp decline in M. haemorrhoidalis abundance coincided with an increase in the emergence of the cuckoo bee $P$. gigas in both years (Figure 2). As also observed by Rozen et al. (2006) and Rocha-Filho and Melo (2011), all specimens of $P$. gigas were only recorded from the emergence traps set in area D.

In 2005-2006, the natural enemies of M. haemorrhoidalis exhibited distinct phenological patterns with a slight overlap between P. gigas and T. distincticollis but only in the first year (Figure 4a). Similarly, the four natural enemies also emerged in different periods in the second year with low overlap occurring between the end of the activity period of a given species and the beginning of the next (Figure 4b). Despite the asynchrony among the four natural enemies, two major patterns were observed: the cleptoparasites, i.e. T. gerardi, P. gigas, and T. distincticollis emerged when $M$. haemorrhoidalis brood cells were being provisioned and the parasitoid $P$. spixi emerged when the activity period of its host had already declined.

\section{DISCUSSION}

In spite of the high diversity of natural enemies found at nest sites of $M$. haemorrhoidalis by Rocha-Filho and Melo (2011), only four species were sampled in the emergence traps. Several mutillid species and the cleptoparasitic flies Heterostylum maculipennis Cunha \& Lamas (Bombyliidae) and Megaselia sp. (Phoridae) were rarely observed, while $T$. gerardi, $P$. gigas, and $T$. distincticollis were the most abundant species (Rocha-Filho and Melo 2011). Massive nest aggregations seem to attract a large number of bee natural enemies including meloid beetles and cuckoo bees (Linsley et al. 1980; Rocha-Filho et al. 2008).

Asynchrony in emergence among cleptoparasitic and parasitoid species, as observed here between the 

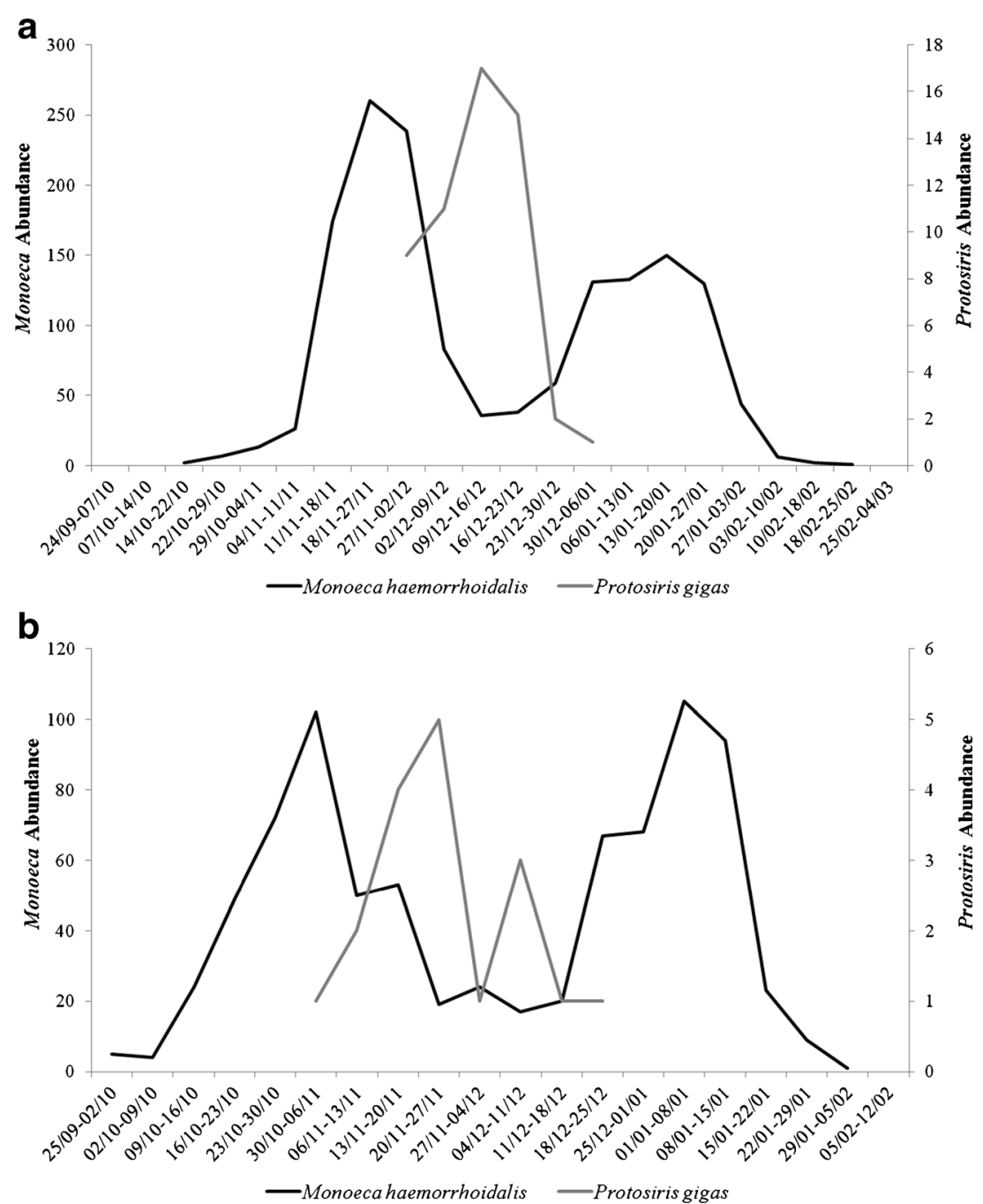

Figure 2. Emergence periods of Monoeca haemorrhoidalis and its cleptoparasite Protosiris gigas in the emergence traps set in areas B and D in the nesting sites, in southern Brazil. a year 1; b year 2

three cleptoparasites and the mutillid parasitoid, has also been observed in other studies (Wcislo et al. 1994; Polidori et al. 2009). As cleptoparasites depend on brood cells being provisioned by host females to parasitize (Wcislo 1987), it is expected that they will be most common during the nesting activities of the host species. Parasitoids such as mutillid wasps, on the other hand, attack cells containing the host's late instar larvae or pupae (Brothers et al. 2000), thus they would emerge after the peak of host brood cell provisioning.
The different phenological patterns between the three cleptoparasitic species of $M$. haemorrhoidalis could be a strategy to avoid competition for host brood cells being provisioned. Meloid beetles and cuckoo bees diverge regarding the methods to gain access to host nests. While females of $P$. gigas invade nests and then access brood cells directly, the meloid triungulins were likely transported to the nests by phoresy on the host bees (Rocha-Filho and Melo 2011). Meloid females can oviposit on flowers, allowing thus their parasitic larvae to reach 


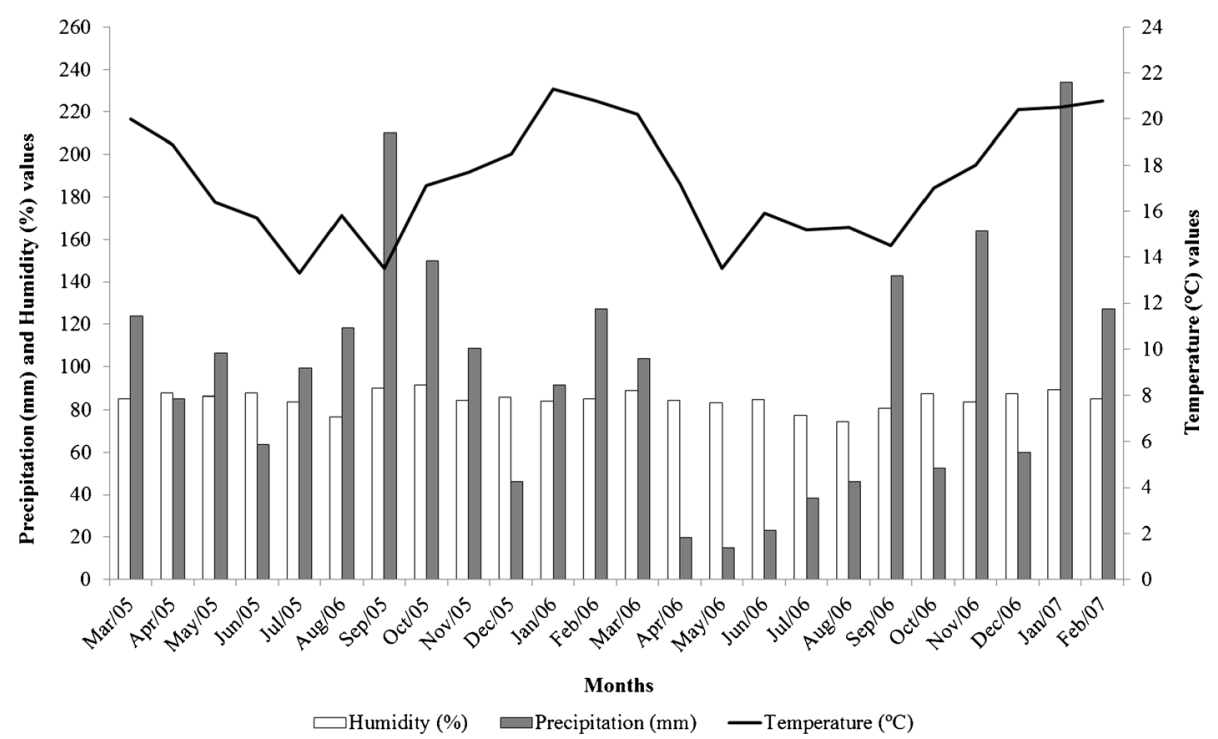

Figure 3. Monthly values of climate variables (relative air humidity (\%), annual precipitation (in mm) and temperature (in ${ }^{\circ} \mathrm{C}$ )) measured from March 2005 to February 2007 in the Meteorological Station of Pinhais, southern Brazil

the host nests by infesting bees when they are foraging (Erickson et al. 1976). As adults of T. gerardi were observed feeding on flowers of Niedenzuella acutifolia (Cav.) W.R. Anderson (Malpighiaceae), the main pollen and oil source of M. haemorr hoidalis, thus it seems likely that this plant act as an oviposition substrate for the female beetles (Rocha-Filho and Melo 2011).

Host species are expected to evolve adaptations against their parasites. Examples of counterstrategies exhibited by host species include mechanisms to protect their nests such as opening brood cells for inspection (Batra and Bohart 1969), tunnel diameter constriction (Linsley et al. 1980), and presence of cells filled with earth (Rocha-Filho et al. 2008). In the system studied here, Rocha-Filho and Melo (2011) have documented a temporal segregation in the daily activities between $M$. haemorrhoidalis and its bee cleptoparasite $P$. gigas which could represent a behavioral strategy to diminish the chances of a successful attack to the newly provisioned brood cells. While the activity period of females of $M$. haemorrhoidalis ranged, mostly, from 7.30 to $12.00 \mathrm{~h}$, those of $P$. gigas were active on nest aggregations only from 10.00 to $15.00 \mathrm{~h}$. Cleptoparasites such as
$P$. gigas that attack only fully provisioned and newly sealed brood cells (Rozen et al. 2006) have to wait for the right moment to enter the host nests. Therefore, the early morning hours, when $P$. gigas were still sleeping on leaves (Rocha-Filho and Melo 2011), could be a "window of opportunity" to host females to accelerate the cell provisioning and avoid clepto-parasite attack. Additional examples of temporal behavioral strategies include those of females of the bee Anthophora flexipes Cresson (Apidae) that are active from sunrise to sundown, while its bee cleptoparasite Zacosmia maculata (Cresson) (Apidae) has a shorter period of daily activity (Torchio and Youssef 1968). The temporal segregation between the cuckoo wasp Argochrysis armilla Bohart (Chrysididae) and its host Ammophila dysmica Menke (Sphecidae) reduced the probability of parasites discovering nests excavated in the early morning and late afternoon (Rosenheim 1989). Likewise, the shift of maximum activity of the beewolf Philanthus triangulum (Fabricius) (Crabronidae) to the evening hours might be a flexible response to the presence of the chrysidid, Hedychrum rutilans Dahlbom, once the brood parasite 

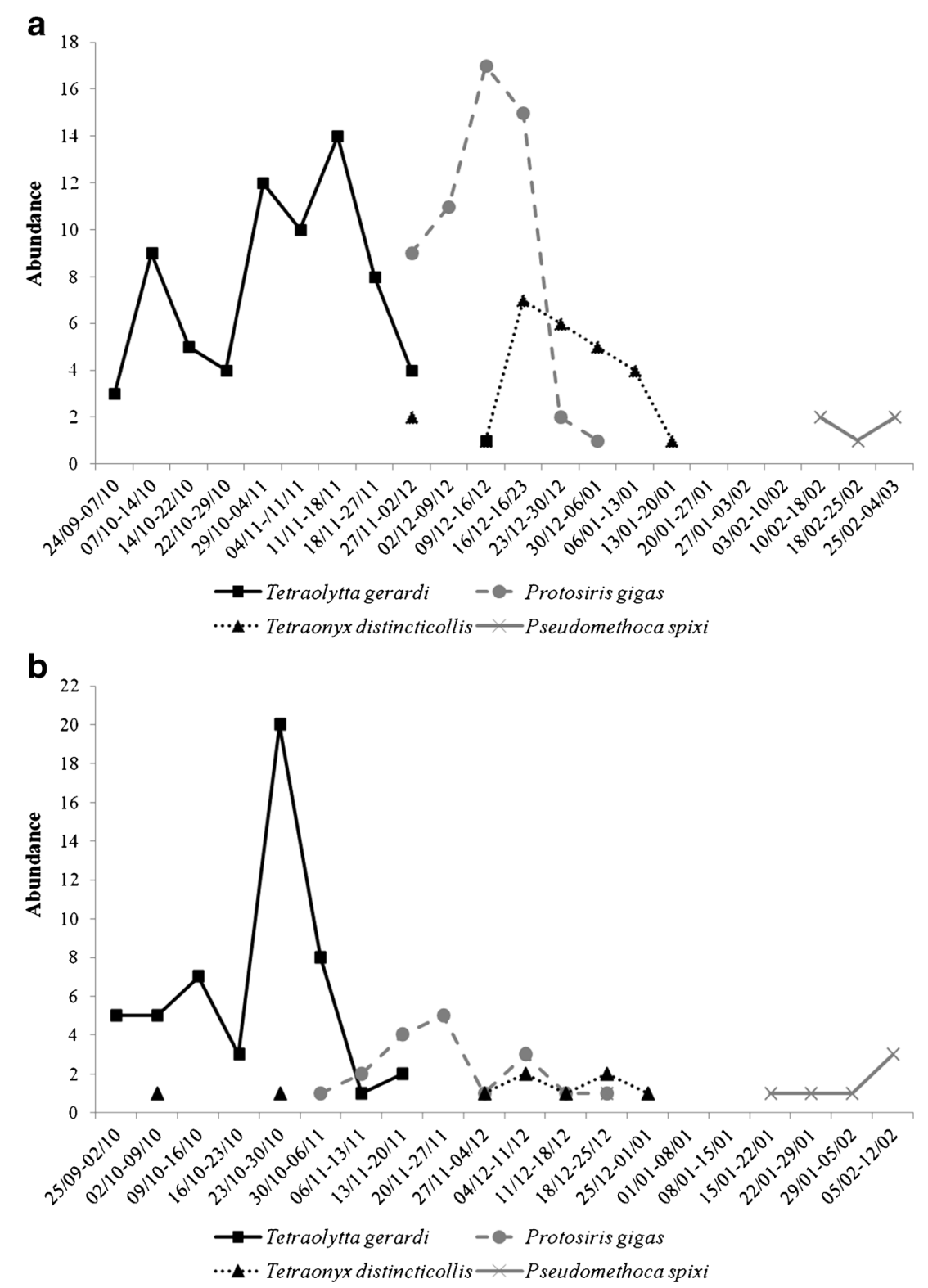

Figure 4. Emergence periods of the species of natural enemies of Monoeca haemorrhoidalis in the traps set in the areas $\mathrm{B}$ and $\mathrm{D}$ in the nesting sites, in southern Brazil. a year $1 ; \mathbf{b}$ year 2

activity declined in the course of the day (Strohm et al. 2001).

On the other hand, the mismatch in the phenology patterns between $M$. haemorrhoidalis and $P$. gigas seems to represent a more effective strategy against the parasite attacks. As $P$. gigas is one of the most abundant natural enemies of $M$. haemorr hoidalis, avoiding this cleptoparasite by reducing the nest activities may act as an important counterstrategy employed by the host bee. The abrupt decline in the emergence period of $M$. haemorr hoidalis could be a temporal strategy against the attack of $P$. gigas since the activity period of this cleptoparasite coincided with the lowest number of emergent host individuals. Even though the emergence of $P$. gigas specimens started during the first 
peak of M. haemorrhoidalis individuals, the phenology of this cleptoparasite was followed by the decline in abundance of its host species. In both years, M. haemorrhoidalis individuals were active between October and February. On the other hand, adults of $P$. gigas were recorded from midNovember 2005 to early January 2006 in the first year and between late October to late December 2006 (Rocha-Filho and Melo 2011). Therefore, brood cells built by $M$. haemorrhoidalis during most of January and February are free of $P$. gigas attack. Females of M. haemorrhoidalis nesting later in the season, however, might have to withstand more restrictive conditions, such as shortage of food sources and more unstable weather conditions. Further studies are required to dissect this remarkable system in order to reveal the benefits and costs associated with each of the two distinct periods of nesting activity exhibited by the host bee.

\section{ACKNOWLEDGMENTS}

We thank Solange Augusto, Laurence Packer, and the two anonymous referees for the critical reading and constructive comments that contributed to improve the manuscript and the taxonomists John Pinto (Meloidae) and Roberto Cambra (Mutillidae). The first author is grateful to "Conselho Nacional de Desenvolvimento Científico e Tecnológico-CNPq" for financial support (award number 130784/2005-2) and SIMEPAR for supplying climatological data.

Jeu de cache-cache: l'abeille solitaire Monoeca haemorrhoidalis tente-t-elle d'échapper à son cleptoparasite Protosiris gigas (Hymenoptera, Apidae: Tapinotaspidini; Osirini)?

cleptoparasitisme/relation hôte-parasite/ennemi naturel/ségrégation par le temps /période d'activité

Versteckspiel: Versucht die solitäre Biene Monoeca haemorrhoidalis ihrem Kleptoparasiten Protosiris gigas (Hymenoptera, Apidae: Tapinotaspidini; Osirini) zu entkommen?

Kleptoparasitismus/Wirt-Parasit-Beziehung/ natürlicher Feind/zeitliche Trennung

\section{REFERENCES}

Alves-dos-Santos, I., Melo, G.A.R., Rozen, J.G. (2002) Biology and immature stages of the bee tribe Tetrapediini (Hymenoptera: Apidae). Am. Mus. Novit. 3377, $1-45$.

Batra, S.W.T. (1966) The life cycle and behavior of the primitively social bee Lasioglossum zephyrum (Halictidae). Univ. Kans. Sci. Bull. 46 (10), 359-423.

Batra, S.W.T. (1984) Solitary bees. Sci. Am. 250 (2), 86-93.

Batra, S.W.T., Bohart, G.E. (1969) Alkali bees: response of adults to pathogenic fungi in brood cells. Science. 165 (3893), 607-608.

Bohart, G.E., Youssef, N. (1972) Notes on the biology of Megachile (Megachiloides) umatillensis Mitchell (Hymenoptera: Megachilidae) and its parasites. Trans. R. Entomol. Soc. Lond. 124 (1), 1-19.

Bohart, G.E., Stephen, W.P., Eppley, R.K. (1960) The biology of Heterostylum robustum (Diptera: Bombyliidae), a parasite of the alkali bee. Ann. Entomol. Soc. Am. 53 (3), 425-435.

Bologna, M.A., Pinto, J.D. (2007) Rediscovery of Tetraolytta gerardi (Pic) (Coleoptera: Meloidae), an enigmatic blister beetle from Brazil: redescription and taxonomic placement. Proc. Entomol. Soc. Wash. 109 (4), 765-772.

Brothers, D.J., Tschuch, G., Burger, F. (2000) Associations of mutillid wasps (hymenoptera: Mutillidae) with eusocial insects. Insectes Soc. 47 (3), 201-211.

Erickson, E.H., Enns, W.R., Werner, F.G. (1976) Bionomics of the bee-associated Meloidae (Coleoptera); bee and plant hosts of some Nearctic meloid beetles - a synopsis. Ann. Entomol. Soc. Am. 69 (5), 959-970.

Evans, H.E. (1966) The comparative ethology and evolution of the sand wasps. Harvard University Press, Cambridge.

Garófalo, C.A., Rozen, J.G. (2001) Parasitic behavior of Exaerete smaragdina with descriptions of its mature oocyte and larval instars (Hymenoptera: Apidae: Euglossini). Am. Mus. Novit. 3349, 1-26.

ITCF. (1987) Plano de gerenciamento da Área Especial de Interesse Turístico do Marumbi. Instituto de Terras, Cartografia e Florestas do Paraná, Curitiba.

Knerer, G. (1973) Periodizität und Strategie der Schmarotzer einer sozialen Schmalbiene Evylaeus malachurus (K.). Zool. Anz. 190 (1-2), 41-63.

Linsley, E.G., MacSwain, J.W., Michener, C.D. (1980) Nesting biology and associates of Melitoma (Hymenoptera, Anthophoridae). Univ. Calif. Publ. Entomol. $90,1-45$.

Maak, R. (2002) Geografia física do Estado do Paraná. 3rd Edition. Imprensa Oficial, Curitiba.

Michener, C.D. (2007) The bees of the world. 2nd edition. The John Hopkins University Press, Baltimore. 
O’Neill, K.M. (2001) Solitary wasps: behavior and natural history. Cornell University Press, Ithaca.

Polidori, C., Borruso, L., Boesi, R., Andrietti, F. (2009) Segregation of temporal and spatial distribution between kleptoparasites and parasitoids of the eusocial sweat bee, Lasioglossum malachurum (Hymenoptera: Halictidae, Mutillidae). Entomol. Sci. 12 (2), 116-129.

Rocha-Filho, L.C., Melo, G.A.R. (2011) Nesting biology and behavioural ecology of the solitary bee Monoeca haemorrhoidalis (Smith) and its cleptoparasite Protosiris gigas Melo (Hymenoptera: Apidae: Tapinotaspidini; Osirini). J. Nat. Hist. 45 (45-46), 2815-2840.

Rocha-Filho, L.C., Silva, C.I., Augusto, S.C., Gaglianone, M.C. (2008) Nesting behavior and natural enemies of Epicharis (Epicharis) bicolor Smith, 1854 (Hymenoptera Apidae). Trop. Zool. 21, 227-242.

Rosenheim, J.A. (1987) Host location and exploitation by the cleptoparasitic wasp Argochrysis armilla: the role of learning (Hymenoptera: Chrysididae). Behav. Ecol. Sociobiol. 21 (6), 401-406.

Rosenheim, J.A. (1989) Behaviorally mediated spatial and temporal refuges from a cleptoparasite, Argochrysis armilla (Hymenoptera: Chrysididae), attacking a ground-nesting wasp, Ammophila dysmica (Hymenoptera: Sphecidae). Behav. Ecol. Sociobiol. 25 (5), 335-348.

Rosenheim, J.A. (1990) Density-dependent parasitism and the evolution of aggregated nesting in the solitary Hymenoptera. Ann. Entomol. Soc. Am. 83 (3), 277-286.

Rozen, J.G. (1984) Comparative nesting biology of the bee tribe Exomalopsini (Apoidea, Anthophoridae). Am. Mus. Novit. 2798, 1-37.

Rozen, J.G., Snelling, R.R. (1986) Ethology of the bee Exomalopsis nitens and its cleptoparasite (Hymenoptera: Anthophoridae). J. N. Y. Entomol. Soc. 944 (4), 480-488.

Rozen, J.G., Melo, G.A.R., Aguiar, A.J.C., Alves-dos-Santos, I. (2006) Nesting biologies and immature stages of the tapinotaspidine bee genera Monoeca and Lanthanomelissa and of their osirine cleptoparasites Protosiris and Parepeolus (Hymenoptera: Apidae: Apinae). Am. Mus. Novit. 3501, 1-60.

Simon-Thomas, R.T., Simon-Thomas, A.M.J. (1972) Some observations on the behavior of females of Philanthus triangulum (F.) (Hymenoptera, Sphecidae). Tijdschr. Entomol. 115 (2), 123-139.

Strohm, E., Kroiss, J., Herzner, G., Laurien-Kehnen, C., Boland, W., Schreier, P., Schmitt, T. (2008) A cuckoo in wolves' clothing? Chemical mimicry in a specialized cuckoo wasp of the European beewolf (Hymenoptera, Chrysididae and Crabronidae). Front. Zool. 5 (2). doi: 10.1186/1742-9994-5-2

Strohm, E., Laurien-Kehnen, C., Bordon, S. (2001) Escape from parasitism: spatial and temporal strategies of a sphecid wasp against a specialised cuckoo wasp. Oecologia 129 (1), 50-57.

Struminski, E. (2001) Parque Estadual Pico do Marumbi. Editora da Universidade Federal do Paraná, Curitiba.

Tengö, J., Bergström, G. (1977) Cleptoparasitism and odor mimetism in bees: do Nomada males imitate the odor of Andrena females? Science 196 (4294), 1117-1119.

Torchio, P.F., Youssef, N.N. (1968) The biology of Anthophora (Micranthophora) flexipes and its cleptoparasite, Zacosmia maculata, including a description of the immature stages of the parasite (Hymenoptera: Apoidea, Anthophoridae). J. Kans. Entomol. Soc. 41 (3), 289-302.

Vinson, S.B., Frankie, G.W., Coville, R.E. (1987) Nesting habits of Centris flavofasciata Friese (Hymenoptera: Apoidea: Anthophoridae) in Costa Rica. J. Kans. Entomol. Soc. 60 (2), 249-263.

Vinson, S.B., Frankie, G., Rao, A. (2011) Field behavior of parasitic Coelioxys chichimeca (Hymenoptera: Megachilidae) toward the host bee Centris bicornuta (Hymenoptera: Apidae). Apidologie 42, 117-127.

Wcislo, W.T. (1987) The roles of seasonality, host synchrony, and behaviour in the evolution and distribution of nest parasites in Hymenoptera (Insecta) with special reference to bees (Apoidea). Biol. Rev. 62 (4), 515-543.

Wcislo, W.T., Minckley, R.L., Leschen, R.A.B., Reyes, S. (1994) Rates of parasitism by natural enemies of a solitary bee, Dieunomia triangulifera (Hymenoptera, Coleoptera and Diptera) in relation to phenologies. Sociobiology 23 (3), 265-273.

Winterhagen, P. (2015) Strategy for sneaking into a host's home: the cuckoo wasp Omalus biaccinctus (Hymenoptera: Chrysididae) inserts its eggs into living aphids that are the prey of its host. Eur. J. Entomol. 112 (3), 557-559. 